Creative commons User License: CC BY-NC-ND

Abstracted by: EBSCOhost, Electronic Journals Service (EJS),

Google Scholar, Directory of Open Access Journals (DOAJ),

Journal Seek, Scientific Commons,

Food and Agricultural Organization (FAO), CABI and Scopus
Journal of Agricultural Extension

Vol. 21 (3) October, 2017

ISSN(e): 24086851; ISSN(Print); 1119944X

http://journal.aesonnigeria.org

http://www.ajol.info/index.php/jae

Email: editorinchief@aesonnigeria.org

\title{
Climate Change Adaptation Needs of Male and Female Oil Palm Entrepreneurs in Edo State, Nigeria \\ https://dx.doi.org/10.4314/jae.v21i3.16
}

Koyenikan, M. J.

Department of Agricultural Economics and Extension Services, University of Benin, Benin City, Nigeria

Email: margaret.koyenikan@uniben.edu, Phone: +2348142108098

\section{Anozie, 0.}

Department of Agricultural Economics and Extension Services, University of Benin, Benin City, Nigeria

Emil: ogooranozie@gmail.com, Phone:+2348024273056

\section{Abstract}

This study assessed gender dimension to climate change adaptation practice (CCAP) needs of oil palm (Elaeis guineensis) farmers in Edo State, Nigeria. A multistage process involving random and snow ball techniques were used to draw 120 respondents from 14 communities. Data were collected with the aid of a questionnaire and analyzed using frequency count, means, percentages and t-test. Findings show that oil palm farming was dominated by males (78.3\%). $47.5 \%$ of the respondents had a farm size of $<4$ ha and a total mean family size of 6 persons. Males (77.5-99.3\%) were highly involved in on-farm and females (48.3-71.7\%) in off-farm oil palm activities The CCAP considered relevant included appropriate spacing ( $\bar{x}=2.99)$, agro forestry $(\bar{x}=2.79)$ and soil enrichment $(\bar{x}=2.62)$. Major challenges to accessing relevant CCAP included inadequate capital $(\bar{x}=2.86)$ and poor extension service $(\bar{x}=2.60)$. Training needs were indicated by females mostly in marketing forecast $(\bar{x}=3.00)$, palm oil storage $(\bar{x}=2.91)$ maintenance of equipment $(\bar{x}=2.89)$ while for males, spacing $(\bar{x}=2.94)$, equipment maintenance $(\bar{x}=2.91)$ and soil enrichment $(\bar{x}=2.91)$. Significant difference existed between male and female respondents $[\overline{\mathrm{x}}=24.65<27.96)$ with respect to training needs on climate change adaptation oil palm post-harvest practices. The study concludes that capacities be built on climate change adaptation practice needs indicated and also women should be targeted more in post-harvest skill development since they are the key players in oil palm post-harvest.

Keywords: climate change adaptation, male and feamel needs, oil palm in Nigeria 
Creative commons User License: CC BY-NC-ND

Abstracted by: EBSCOhost, Electronic Journals Service (EJS),

Google Scholar, Directory of Open Access Journals (DOAJ),

Journal Seek, Scientific Commons,

Food and Agricultural Organization (FAO), CABI and Scopus
Journal of Agricultural Extension

Vol. 21 (3) October, 2017

ISSN(e): 24086851; ISSN(Print); 1119944X

http://journal.aesonnigeria.org

http://www.ajol.info/index.php/jae

Email: editorinchief@aesonnigeria.org

\section{Introduction}

Oil palm (Elaeis guineensis) is believed to have originated from the tropical rain forest region of West Africa. According to FAO (2007) report, oil palm cultivation is indigenous to southern Nigeria and it is part of their way of life. It is often referred to as a crop with multiple values and this underscores its economic value especially in the tropics. Every part of the oil palm is beneficial. Oladipo (2008) reported that oil palm is suitable for low cost and low technology activities such as; palm ribs and fronds for roofing and thatching, brooms, baskets, wickerwork and mats while its residue can be used for fire lighting and as energy source. It is also an important source of oils such as palm oil and vegetable oil. Odior (2007) observed that oil palm produces the highest yield of vegetable oil when compared with other oil bearing plants. Palm oil can be used both domestically and industrially and application of palm oil in these areas is continually on the increase (Omereji, 2005). These various uses of oil palm products offer a wide range of employment opportunities (Oladipo, 2008 and Ayodele, 2010) and also results in an increase in demand for palm oil.

The demand for oil palm products made it imperative that ways of improving the crop be sought. This led to the establishment of the Nigerian Institute For Oil palm Research (NIFOR) in Benin City, Edo State in 1939. The primary objective was to genetically improve oil palm by improving its agronomic practices, including planting, cultivation and harvesting techniques, to develop control measures for pests and diseases, processing, preservation, storage and utilization of palm products among other functions (NIFOR, 2006). Through the efforts of NIFOR, Nigeria was noted for oil palm production and Edo State was the major producing State. Production has witnessed a downward trend over the years (Okpamen, Umumarongie-Ilori, Orhue, Suilaman-Ilobu,Eneje and Efetie-Osie, 2012) which could be attributed partly to the challenge posed by climate change to agriculture and the environment.

Rosillo-Calle, Pelkmans and Walter (2009) posited that changing weather pattern can have major geographical impacts and effects on oil palm production. Climate change according to IPCC (2007), is a change in the state of the climate which can be identified by changes in the mean and/or the variability of its properties and that persists for an extended period usually decades or longer. This has a damaging effect on the environment and it has been stated that increased greenhouse effects will further worsen the change in climate. According to UNEP (2011), climate change leads to losses in human, economic, material resources and also has environmental adversities. Specifically, IPCC (2001) stated that agricultural activities have been most vulnerable to climate change. This is because agriculture depends heavily on weather elements such as rainfall and temperature. This could lead to reduced output and consequently low earning from agricultural activities.

Oil palm produces optimally with a minimum rainfall of $1500 \mathrm{~mm}$ all year round, evenly distributed sunshine of above $2000 \mathrm{~h}$ per year and a mean maximum

temperature of between $29^{\circ} \mathrm{C}$ to $33^{\circ} \mathrm{C}$ and a minimum of $22^{\circ} \mathrm{C}$ to $24^{\circ} \mathrm{C}$ (Basiron, 2007; Corley and Tinker, 2003). In the event of a change in the climate, high temperatures may be experienced and this renders the land marginal and unsuitable 
Creative commons User License: CC BY-NC-ND

Abstracted by: EBSCOhost, Electronic Journals Service (EJS), Google Scholar, Directory of Open Access Journals (DOAJ), Journal Seek, Scientific Commons,

Food and Agricultural Organization (FAO), CABI and Scopus
Journal of Agricultural Extension

Vol. 21 (3) October, 2017

ISSN(e): 24086851; ISSN(Print); 1119944X

http://journal.aesonnigeria.org

http://www.ajol.info/index.php/iae

Email: editorinchief@aesonnigeria.org

for oil palm production. Corley and Tinker (2003) also observed that lack of water can lead to decreased production of oil palm male and female flowers. They further stated that drought also causes flower drop and reduced crop production. Other effects include; decreased in fresh fruit bunch (FFB) yields which will affect the frequency and severity of moisture stress experienced by palms thereby delaying harvest activities and ultimately if left for a long time the oil palm will rot. The edaphic factors are also affected by climate change, NOAA (2011) reported that drastic increase in rainfall intensity and duration which causes flooding also leads to acute soil problems, such as nutrient loss in oil palm production. In line with the above, Li et al., (2011) reported that climate change has a negative economic impacts on the agricultural production, prices, demand, trade, regional comparative advantage, producers' and consumers' welfare. These are usually men and women who perform different roles in oil palm value chain.

A United Nations Development Programme (UNDP) report (2010) on Gender and Climate change capacity development series evidenced that climate change has an adverse effect on the lives and livelihoods of men and women, their families and communities. They further posited that these impacts affect men and women differently because of their gender-based roles and this exacerbate existing gender inequalities. IPCC (2007); Toulmin (2009) and Women Watch (2009) noted that climate change is intrinsically linked with poverty and economic marginalization and thus since women constitute the highest percentage of the world's poor, they are most affected by these changes. The vulnerability of women to climate change is also as a result of the fact that most rural women engage in livelihood activities that are highly dependent on natural resources and these natural resources are highly climate sensitive (FAO, 2011 and Dankelman, 2010). For instance, agriculture, a highly climate sensitive sector supports the livelihood of $70-80 \%$ of farmers in Nigeria bulk of which are women.

Institute for Oil Palm Research (NIFOR) developed some improved technologies which include use of improved varieties, inorganic fertilizers, insecticides, herbicides, ring weeding, pruning practices and use of leguminous crops as cover crop. However, UNDP (2010) reported that the capacity to adapt to these technologies differ between men and women. For these reasons there is need to assess the gender dimensions to adaptation technologies/information needs, taking into cognizance the needs of both men and women so as to create opportunities for sustainable development. More so Edo state is one of the major producing areas of oil palm in Nigeria and by extension, the largest producers of palm oil and palm kernels in Nigeria. It is therefore, the concern of this study to identify the reasons or the problems responsible for the falling level of oil palm production in the area of study and also to render useful suggestions and solutions.

Based on the foregoing, this study seeks to examine the gender dimensions to climate change adaptation practice needs of oil palm entrepreneurs in Edo State, Nigeria. To achieve this, the following specific objectives were set to;

1. describe the socio economic characteristics of the respondents;

2. ascertain the perceived relevance of climate change adaptive practices; 
Creative commons User License: CC BY-NC-ND

Abstracted by: EBSCOhost, Electronic Journals Service (EJS),

Google Scholar, Directory of Open Access Journals (DOAJ),

Journal Seek, Scientific Commons,

Food and Agricultural Organization (FAO), CABI and Scopus
Journal of Agricultural Extension

Vol. 21 (3) October, 2017

ISSN(e): 24086851; ISSN(Print); 1119944X

http://journal.aesonnigeria.org

http://www.ajol.info/index.php/jae

Email: editorinchief@aesonnigeria.org

3. identify the climate change adaptive practices and information needs; and

4. identify constraints to knowledge of climate change adaptive practices.

Ho: There is no significant difference between male and female respondents with respect to climate change adaptive practice needs.

\section{Methodology}

Edo State is an inland state in central southern Nigeria. It lies within the geographical co-ordinates of longitude $6^{\circ} 04^{\prime} \mathrm{E}$ and $6^{\circ} 43^{\prime} \mathrm{E}$ and latitude $5^{\circ} 44^{\prime} \mathrm{N}$ and $7^{\circ} 34^{\prime} \mathrm{N}$ of the equator. Its capital is Benin City. It is bounded in the south by Delta State, in the West by Ondo State, in the North by Kogi State and in the east by Kogi and Anambra States. The state occupies an area of $17,802 \mathrm{~km}^{2}(6,8773 \mathrm{sq} \mathrm{mi})$ with a population of over 3million.

Edo State is located in the Rainforest zone of Southern Nigeria. The annual precipitation is between $1500 \mathrm{~mm}$ and $3000 \mathrm{~mm}$ with rainfall days of about 200 . The mean annual rainfall in the northern part of the State is between $127 \mathrm{~cm}-152$ which the southern part of the state receives about $252 \mathrm{~cm}-254 \mathrm{~cm}$ of rainfall annually. The three distinct vegetation types are mangrove forest, fresh swamp, savannah. The state is divided into three agro-ecological zones: Edo North (comprises of 7 LGAs), Edo Central (comprises of 5 LGAs) and Edo South (comprises of 6 LGAs). The major occupation of the people is agriculture. About 200,000 largely subsistence farm families are responsible for $80 \%$ of agricultural production in the state and most of the farmers are engaged in arable crop production (www.edostate.gov.ng/commercialagriculture). The State is noted for the production of tree crops such as oil palm, rubber, cocoa and cashew nuts.

A multistage process was used to select respondents for the study. The first stage was the purposive selection of one out of the three agro ecological zones in Edo state, at this stage Edo south was selected. Edo south was purposively selected because it has the highest concentration of oil palm farmers. This was followed by the random selection of two communities from each of the seven Local Government Areas that make up Edo south. This summed up to fourteen communities. Lastly, snow balling was used to select nine respondents from each of the communities, to give a sample size of 126 respondents. However, only 120 questionnaires were considered valid. The primary data were collected from farmers through the use of a structured questionnaire. The questionnaire was structured into sections to generate different information that addressed the objectives. Variables were measured as follows;

Perceived relevance of mitigation practices was measured on 3-point scale of nineteen (19) items on production and eight (8) items of post-harvest. The options were coded as very relevant $=3$, relevant $=2$, not relevant $=1$. The mean response was calculated and mean response greater than or equal to 2 was considered as relevant.

Training Need was measured on 3-point scale of nineteen (19) items on production and eight (8) items of post-harvest. The 3-point likert option include; highly needed $=3$, needed $=2$, not needed $=1$. The minimum score is 19 while the maximum is 81 . Mean response greater than or equal to 2 was considered as relevant. 
Creative commons User License: CC BY-NC-ND

Abstracted by: EBSCOhost, Electronic Journals Service (EJS),

Google Scholar, Directory of Open Access Journals (DOAJ),

Journal Seek, Scientific Commons,

Food and Agricultural Organization (FAO), CABI and Scopus
Journal of Agricultural Extension

Vol. 21 (3) October, 2017

ISSN(e): 24086851; ISSN(Print); $1119944 X$

http://journal.aesonnigeria.org

http://www.ajol.info/index.php/jae

Email: editorinchief@aesonnigeria.org

Possible constraints to knowledge of adaptation practices was measured on 3-point scale of very serious coded 3 , serious $=2$, and not serious $=1$. Mean responses greater than or equal to 2.0 were considered as 'serious constraints'.

Data from the study were analyzed using descriptive Statistics which involved frequency, percentage, mean, standard deviation. Inferential Statistics; t-test was used to test the hypothesis at $5 \%$ significant level

\section{Results and Discussion}

Table 1 shows the socio economic characteristics of the respondents. A high percentage $(78.3 \%)$ were males. This may be due to the socio cultural factors which prevents women from possessing an economic tree (such as oil palm). This is in tandem with the finding of Agwu (2006) who noted that traditionally women in Arochukwu LGA were not allowed to own plantation and are thus into processing and marketing of palm produce. Mean age of the male respondents was 52 years while for the female respondents it was 45 years. This shows that the male respondents were relatively old and may not be highly productive while the females are in the middle age which means they are in their active age and may be more productive than their counterpart. This could have a negative effect especially for the male respondents on adaptation of climate change practice. This contradicts the findings of Obinne and Anyanwu (1991) who reported that the mean age of male farmers in their study area was 45 years and that of females was $40 y e a r s$.

About $72 \%$ of the male respondents were married while $19.1 \%$ of the female were married. This implies that most oil palm entrepreneurs in the study area were married. It also implies a sense of responsibility and more commitment to the business which will enhance its productivity. majority $(97.5 \%)$ of both male and female respondents had one form of education or the other. This shows that the respondents are literate and this may positively affect the level of oil palm production and their adaptation to climate change practice. This agrees with the findings of Erhabor and Emokaro (2007), who stated in line with World Bank report, that the output of an educated farmer is 13 percent more than their uneducated counterpart. all the females had formal education but $2.5 \%$ of the male respondents had no formal education. none of the women owned land fully, $13.3 \%$ of them rented land for their oil palm production. half $(50 \%)$ of the men (either fully or joint ownership) owned oil palm lands. Also none of the female respondents had access to communal land for their oil palm business whereas $7.5 \%$ of the men did. This shows that both at household level and at community level women are marginalized and have no access to land. This will not only affect the level of oil palm production but also the adaptation to climate change practices used. This agrees with the report of USAID (2005) which stated that socio cultural differences between male and female affect power allocation, resources, status and duties in any social milieu.

The mean farm size for male respondents was six hectares while for the female counterparts four hectares. This shows that male oil palm farmers in the study area

have access to larger farm size than their female counterparts. Consequently, other things being equal, this will create a difference not only in the level of production and income but also in the ability to adapt to climate change adaptation practice (CCAP). 
Creative commons User License: CC BY-NC-ND

Abstracted by: EBSCOhost, Electronic Journals Service (EJS), Google Scholar, Directory of Open Access Journals (DOAJ), Journal Seek, Scientific Commons,

Food and Agricultural Organization (FAO), CABI and Scopus

\section{Journal of Agricultural Extension}

Vol. 21 (3) October, 2017

ISSN(e): 24086851; ISSN(Print); 1119944X

http://journal.aesonnigeria.org

http://www.ajol.info/index.php/jae

Email: editorinchief@aesonnigeria.org

This agrees with Alamu and Rahman (2002) who observed that farmers with more resources including land were most likely to take advantage of new technology. the mean annual income for the female respondents was $\$ 307,692.60$ while that of the male was $476,596.14$. This shows that the male respondents made more income to the tune of $168,903.54$ (38.4\%) more than their female counterparts. Perhaps this may be as a result of low access to production resources of the female respondents especially land. Intergovernmental Panel on Climate Change (IPCC) (2001) stated that farmers' economic conditions are expressed in terms of economic assets, capital resources or financial means and this determines their adaptation capacity.

\section{Table1: Socio economic characteristics of respondents}

\begin{tabular}{|c|c|c|c|}
\hline & $\begin{array}{l}\text { Male } \\
\%\end{array}$ & $\begin{array}{l}\text { Female } \\
\%\end{array}$ & $\begin{array}{l}\text { Total } \\
\%\end{array}$ \\
\hline Sex & 78.3 & 21.7 & 100 \\
\hline \multicolumn{4}{|l|}{ Age (years) } \\
\hline 30 and below & 2.5 & 2.5 & 5.0 \\
\hline $31-40$ & 1.7 & 1.7 & 3.3 \\
\hline $41-50$ & 27.5 & 10.0 & 37.5 \\
\hline $51-60$ & 33.3 & 7.5 & 40.8 \\
\hline $61-70$ & 13.3 & - & 13.3 \\
\hline Mean & 52 & 45 & 50 \\
\hline \multicolumn{4}{|l|}{ Marital status } \\
\hline Single & 4.2 & - & 4.2 \\
\hline Married & 71.7 & 19.1 & 90.8 \\
\hline Divorced & 2.5 & - & 2.5 \\
\hline Widow(er) & - & 2.5 & 2.5 \\
\hline \multicolumn{4}{|l|}{ Family size } \\
\hline $1-4$ & 10.0 & 0.8 & 10.8 \\
\hline 5- 8 & 52.5 & 20.8 & 73.3 \\
\hline $9-12$ & 15.8 & - & 15.8 \\
\hline Mean & 7 & 6 & 6 \\
\hline \multicolumn{4}{|l|}{ Educational level } \\
\hline No formal education & 2.5 & - & 2.5 \\
\hline Primary education & 29.2 & 6.6 & 35.8 \\
\hline Secondary education & 33.3 & 11.7 & 45.0 \\
\hline Post- secondary education & 13.3 & 3.4 & 16.7 \\
\hline \multicolumn{4}{|l|}{ Land tenureship } \\
\hline Owned land fully & 25.0 & - & 25.0 \\
\hline Joint ownership & 25.0 & 8.3 & 33.3 \\
\hline Rented & 20.9 & 13.3 & 34.2 \\
\hline Communal & 7.5 & - & 7.5 \\
\hline \multicolumn{4}{|l|}{ Farm size (ha) } \\
\hline $1-5$ & 30.8 & 16.7 & 47.5 \\
\hline $6-10$ & 41.7 & 5.0 & 46.7 \\
\hline $11-15$ & 5.8 & - & 5.8 \\
\hline Mean & 6 & 4 & 6 \\
\hline \multicolumn{4}{|l|}{ Annual income (Naira) } \\
\hline 200,000 and below & 15.8 & 9.2 & 25.0 \\
\hline $200,001-400,000$ & 12.5 & 5.0 & 17.5 \\
\hline $400,001-600,000$ & 24.2 & 5.0 & 29.2 \\
\hline $600,001-800,000$ & 16.7 & 2.5 & 19.2 \\
\hline $800,001-1,000,000$ & 9.2 & - & 9.2 \\
\hline Mean & 476,596 & 307,692 & 440,000 \\
\hline
\end{tabular}

Source: Field survey, 2014

\section{Perceived Relevance of Climate Change Adaptation Practices}

Results on Table 2 show respondents perceived relevance of climate change adaptation practices (CCAPs). For production/on-farm activities, both male and female respondents perceived almost all the adaptation practices to be relevant. Some of these relevant practices, for male and female respondents, respectively 
Creative commons User License: CC BY-NC-ND

Abstracted by: EBSCOhost, Electronic Journals Service (EJS),

Google Scholar, Directory of Open Access Journals (DOAJ),

Journal Seek, Scientific Commons,

Food and Agricultural Organization (FAO), CABI and Scopus

\author{
Journal of Agricultural Extension \\ Vol. 21 (3) October, 2017 \\ ISSN(e): 24086851; ISSN(Print); 1119944X \\ http://journal.aesonnigeria.org \\ http://www.ajol.info/index.php/jae \\ Email: editorinchief@aesonnigeria.org
}

includes, zero tillage of the soil $(\bar{x}=2.81$ and 2.85$)$, use of irrigation schemes $(\bar{x}=$ 2.49 and 2.54), integrated pest management ( $\bar{x}=2.65$ for both) and planting of drought resistant varieties $(\bar{x}=2.06$ and 2.04). This shows that the effect of climate change is being felt in the study area and it is affecting production of oil palm in the area. This is concomitant with the submission of IPCC (2001) which stated that agricultural activities have been most vulnerable to climate change. This is because agriculture depends heavily on weather elements such as rainfall and temperature. This could lead to reduced output and consequently low earning from agricultural activities. Also, avoiding indiscriminate bush burning was perceived relevant by the male $(\bar{x}=2.28)$ but their female counterparts perceived it as irrelevant $(\bar{x}=1.77)$. This may perhaps be tied to the fact that most of the female respondents are tenants (rented their oil palm lands) and as such could not do much without the permission of the land owner.

On post-harvest practices, respondents perceived all the adaptation strategies as being relevant. However, the male respondents considered water use and conservation as not relevant $(\bar{x}=1.94)$, their female counterparts considered it relevant $(\overline{\mathrm{x}}=2.96)$. This may be due to the fact that majority of females are not land owners hence cannot practice water use and conservation which is required since they are the key players in fresh fruit bunch (FFB) processing which entails the use of large volume of water. Corroborating this finding, IWMI (2009) asserted that investment in improved agricultural water management is affected by access to water, which is linked to land tenure, hence secure land tenure is a prerequisite to investments in climate change adaptations related to land and water management. 
Creative commons User License: CC BY-NC-ND

Abstracted by: EBSCOhost, Electronic Journals Service (EJS), Google Scholar, Directory of Open Access Journals (DOAJ), Journal Seek, Scientific Commons,

Food and Agricultural Organization (FAO), CABI and Scopus
Journal of Agricultural Extension

Vol. 21 (3) October, 2017

ISSN(e): 24086851; ISSN(Print); $1119944 X$

http://journal.aesonnigeria.org

http://www.ajol.info/index.php/jae

Email: editorinchief@aesonnigeria.org

Table2: Perceived relevance of climate change adaptation practices

\begin{tabular}{|c|c|c|c|c|c|c|}
\hline \multirow[b]{2}{*}{ Climate change adaptation practices } & \multicolumn{2}{|c|}{ Male } & \multicolumn{2}{|c|}{ Female } & \multicolumn{2}{|c|}{ Total } \\
\hline & Mean & SD & Mean & SD & Mean & SD \\
\hline \multicolumn{7}{|l|}{ Production /On-farm Activities } \\
\hline Appropriate spacing of plants on the farm & $2.99 *$ & .10 & $3.00^{*}$ & .00 & $2.99^{*}$ & .09 \\
\hline Avoidance of bush burning & $2.74^{*}$ & .59 & $2.96^{*}$ & .20 & $2.79^{*}$ & .53 \\
\hline $\begin{array}{l}\text { Soil enrichment measures like application of } \\
\text { fertilizers }\end{array}$ & $2.59^{*}$ & .77 & $2.77^{*}$ & .65 & $2.62^{*}$ & .75 \\
\hline Use of irrigation scheme & $2.49^{*}$ & .67 & $2.54^{*}$ & .58 & $2.50^{*}$ & .65 \\
\hline Zero tillage of the soil & $2.81^{*}$ & .68 & $2.85^{*}$ & .73 & $2.83^{*}$ & .69 \\
\hline Planting of cover crops /Agroforestry & $2.74^{*}$ & .79 & $2.81^{*}$ & .75 & $2.78^{*}$ & .78 \\
\hline Mulching of the soil and plants & $2.59^{*}$ & .74 & $2.65^{*}$ & .80 & $2.62^{*}$ & .75 \\
\hline Integrated pest management & $2.65^{*}$ & .48 & $2.65^{\star}$ & .49 & $2.65^{*}$ & .48 \\
\hline Weather forecasting for planting & $2.59^{*}$ & .69 & $2.50^{*}$ & .71 & $2.57^{*}$ & .69 \\
\hline Bush fallowing & $2.55^{*}$ & .63 & $2.65^{*}$ & .56 & $2.57^{*}$ & .62 \\
\hline Adjustment of farming programme & $2.54^{*}$ & .79 & $2.46^{*}$ & .76 & $2.53^{*}$ & .78 \\
\hline Planting date adjustment & $2.40^{*}$ & .87 & $2.50^{*}$ & .81 & $2.43^{*}$ & .86 \\
\hline Planting of early maturing species & $2.28^{*}$ & .75 & $2.15^{*}$ & .73 & $2.25^{\star}$ & .75 \\
\hline Manuring & $2.07^{*}$ & .68 & $2.15^{*}$ & .73 & $2.09^{*}$ & .69 \\
\hline Planting drought tolerant species & $2.06^{*}$ & .72 & $2.04^{*}$ & .53 & $2.06^{*}$ & .68 \\
\hline Avoid indiscriminate bush burning & $2.48^{*}$ & .74 & 1.77 & .91 & 1.54 & .79 \\
\hline Planting wind breakers & $2.39^{*}$ & .55 & $2.54^{*}$ & .51 & $2.47^{*}$ & .54 \\
\hline Improved weeding method - use of herbicide & $2.54^{*}$ & .83 & $2.05^{*}$ & .49 & $2.30^{*}$ & .77 \\
\hline $\begin{array}{l}\text { Clearing of the land with improved } \\
\text { tools/machineries }\end{array}$ & $2.27^{*}$ & .82 & $2.00^{*}$ & .64 & $2.14^{*}$ & .71 \\
\hline $\begin{array}{l}\text { Harvesting information (timeliness and method } \\
\text { Post harvest practices }\end{array}$ & $2.46^{*}$ & .83 & $2.05^{*}$ & .66 & $2.26^{*}$ & .66 \\
\hline Palm nut handling & $2.32^{*}$ & .79 & $2.05^{\star}$ & .48 & $2.19^{*}$ & .80 \\
\hline Marketing information & $2.51^{*}$ & .81 & $2.11^{*}$ & .71 & $2.31^{*}$ & .56 \\
\hline Maintenance of equipments & $2.22^{*}$ & .66 & $2.05^{*}$ & .74 & $2.14^{*}$ & .54 \\
\hline Water use and conservation & 1.94 & .45 & $2.96^{*}$ & .43 & $2.45^{\star}$ & .61 \\
\hline Improved extraction method & $2.16^{*}$ & .64 & $2.00^{*}$ & .51 & $2.08^{*}$ & .62 \\
\hline Improved storage method & $2.14^{*}$ & .73 & $2.00^{*}$ & .59 & $2.07^{*}$ & .56 \\
\hline Improved sterilization method & $2.08^{*}$ & .59 & $2.44^{*}$ & .68 & $2.26^{*}$ & .89 \\
\hline Improved threshing method & $2.41^{*}$ & .56 & $2.84^{*}$ & .30 & $2.63^{*}$ & .50 \\
\hline
\end{tabular}

Source: Field survey, 2014

Mean $>2.00=$ relevant

\section{Training Needs of Respondents on Climate Change Adaptation Practices}

Table 3 shows climate change training needs of respondents. respondents affirmed that they need training in almost all the climate change practices listed. This confirms the results on Table 2 . When a practices/technology is considered relevant, training on such practices/technology becomes essential; since respondents perceived most of the climate change practices as relevant they are likely to embrace trainings in these practices. Disaggregating the data, reveals that; weather forecasting for planting $(\overline{\mathrm{x}}=1.86)$ was not considered a training need by the male respondents but their female counterpart dims it as a training need $(\bar{x}=2.03, S D=0.27)$, though this was not agreed across the female population. Since majority of the respondents had one form of education or the other (Table 1), they may be aware that weather forecasting is done by the weather forecasters and as such do not consider it a training need. Adjustment of farming programme $(\overline{\mathrm{x}}=2.85)$ was considered a training need by the male respondents, however the female (mean=1.03) do not considered it as one. This may be tied to the fact that since women do not control one of the 
Creative commons User License: CC BY-NC-ND

Abstracted by: EBSCOhost, Electronic Journals Service (EJS), Google Scholar, Directory of Open Access Journals (DOAJ), Journal Seek, Scientific Commons,

Food and Agricultural Organization (FAO), CABI and Scopus
Journal of Agricultural Extension

Vol. 21 (3) October, 2017

ISSN(e): 24086851; ISSN(Print); 1119944X

http://journal.aesonnigeria.org

http://www.ajol.info/index.php/jae

Email: editorinchief@aesonnigeria.org

most important production resources, that is land, they are not at liberty to make decisions on what should or should not be planted on the land.

While the female respondents considered palm nut handling $(\bar{x}=2.70)$, marketing information ( $\bar{x}=2.51)$ and maintenance of equipment $(\bar{x}=2.57)$ as training needs for climate change postharvest practices, the male respondents' needs were on the contrary $(\bar{x}=1.93,1.86$ and 1.36$)$, respectively. This shows that women in the study area are not only involved in oil palm production but are also involved in the processing and marketing of palm oil more than their male counterparts. This agrees with the findings of Sarku (2016) who observed that men and women perform different tasks in oil palm production, while the female are more into marketing and processing the males are more of production.

Table 3: Climate change training needs of respondents

\begin{tabular}{|c|c|c|c|c|c|c|}
\hline & \multicolumn{2}{|c|}{ Male } & \multicolumn{2}{|c|}{ Female } & \multicolumn{2}{|c|}{ Total } \\
\hline & Mean & SD & Mean & SD & Mean & SD \\
\hline \multicolumn{7}{|l|}{ Production /On-farm Activities } \\
\hline Appropriate spacing of plants on the farm & $2.44^{\star}$ & .86 & $2.49^{*}$ & .48 & $2.47^{*}$ & .60 \\
\hline Avoidance of bush burning & $2.39^{*}$ & .86 & $2.43^{*}$ & .71 & $2.41^{*}$ & .00 \\
\hline $\begin{array}{l}\text { Soil enrichment measures like application of } \\
\text { fertilizers }\end{array}$ & $2.42^{*}$ & .83 & $2.46^{*}$ & .72 & $2.44^{*}$ & .73 \\
\hline Use of irrigation scheme & $2.34^{\star}$ & 85 & $2.46^{*}$ & .46 & $2.40^{*}$ & .61 \\
\hline Zero Tillage of the soil & $2.34^{*}$ & .80 & $2.49^{*}$ & .33 & $2.42^{*}$ & .45 \\
\hline Planting of cover crops /Agroforestry & $2.28^{*}$ & .82 & $2.24^{*}$ & .16 & $2.26^{*}$ & .69 \\
\hline Mulching of the soil and plants & $2.17^{*}$ & .73 & $2.16^{*}$ & .33 & $2.17^{*}$ & .75 \\
\hline Planting of wind breakers & $2.16^{*}$ & .79 & $2.16^{*}$ & .78 & $2.16^{*}$ & .57 \\
\hline Integrated pest management & $2.63^{*}$ & .66 & $2.86^{*}$ & .53 & $2.75^{*}$ & .54 \\
\hline Weather forecasting for planting & 1.86 & .64 & $2.03^{*}$ & .27 & 1.95 & .69 \\
\hline Bush fallowing & $2.86^{*}$ & .61 & $2.05^{*}$ & .21 & $2.46^{*}$ & .40 \\
\hline Adjustment of farming programme & $2.85^{*}$ & .50 & 1.03 & .16 & 1.94 & 39 \\
\hline Planting date adjustment & $2.84^{*}$ & .51 & $2.03^{*}$ & .22 & $2.44^{*}$ & 48 \\
\hline Planting of early maturing species & $2.85^{*}$ & .61 & $2.62^{*}$ & .17 & $2.74^{*}$ & .44 \\
\hline Manuring & $2.58^{*}$ & .99 & $2.84^{*}$ & .38 & $2.71^{*}$ & .38 \\
\hline Planting drought tolerant species & $2.60^{*}$ & .99 & $2.86^{*}$ & .46 & $2.73^{*}$ & 39 \\
\hline Avoid indiscriminate bush burning & $2.26^{*}$ & .98 & $2.68^{*}$ & .53 & $2.47^{*}$ & .52 \\
\hline Planting wind breakers & 1.41 & .98 & $2.78^{*}$ & .62 & $2.10^{*}$ & .47 \\
\hline Improved Weeding method - use of herbicide & $2.64^{*}$ & .45 & $3.84^{*}$ & .44 & $3.24^{*}$ & .34 \\
\hline $\begin{array}{l}\text { Clearing of the land with improved } \\
\text { tools/machineries }\end{array}$ & $2.99^{*}$ & .20 & $2.81^{*}$ & .37 & $2.93^{*}$ & .25 \\
\hline $\begin{array}{l}\text { Harvesting information (timeliness and method } \\
\text { Post harvest practices }\end{array}$ & $2.48^{*}$ & .63 & $2.78^{*}$ & 43 & $2.78^{*}$ & .61 \\
\hline Palm nut handling & 1.93 & .25 & $2.70^{*}$ & .40 & $2.91^{*}$ & .29 \\
\hline Marketing information & 1.86 & 28 & $2.51^{*}$ & .40 & $2.89^{*}$ & .31 \\
\hline Maintenance of equipments & 1.36 & .36 & $2.57^{*}$ & .37 & $2.85^{*}$ & .36 \\
\hline Water use and conservation & $2.80^{*}$ & .43 & $2.51^{*}$ & .40 & $2.80^{*}$ & .42 \\
\hline Improved Extraction method & $2.78^{*}$ & .62 & $2.38^{*}$ & .54 & $2.79^{*}$ & .61 \\
\hline Improved storage method & $2.74^{*}$ & .44 & $2.38^{*}$ & .33 & $2.77^{*}$ & .42 \\
\hline Improved sterilization method & $2.74^{*}$ & .53 & $2.05^{*}$ & .75 & $2.72^{*}$ & .58 \\
\hline Improved Threshing method & $2.64^{*}$ & .55 & $2.38^{*}$ & .46 & $2.68^{*}$ & .53 \\
\hline
\end{tabular}


Creative commons User License: CC BY-NC-ND

Abstracted by: EBSCOhost, Electronic Journals Service (EJS), Google Scholar, Directory of Open Access Journals (DOAJ), Journal Seek, Scientific Commons

Food and Agricultural Organization (FAO), CABI and Scopus
Journal of Agricultural Extension

Vol. 21 (3) October, 2017

ISSN(e): 24086851; ISSN(Print); 1119944X

http://journal.aesonnigeria.org

http://www.ajol.info/index.php/jae

Email: editorinchief@aesonnigeria.org

\section{Constraints to Accessing Climate Change Information}

Table 4 reveals that ten (10) out of thirteen (13) constraints listed were considered serious. This implies that respondents faced myriads of constraints which hinder them from assessing climate change information and practices. Unavailability of funds ( $\bar{x}=2.85$ for males and 2.88 for females) and poor access to land $(\bar{x}=2.74$ for males and 2.81 for females) were both rated as the most serious constraints faced by both categories of respondents, however the males perceived them less serious than the females. This implies that respondents do not have financial capacity to avail themselves some of these climate change adaptation practices. This aligns with IPCC's report (2001) which noted that poverty is directly related to vulnerability, and is therefore a rough indicator of the ability to cope and adapt. Furthermore, they stated that adaptation and adoption of new technology costs money, and because poor farmers have less diverse and more restricted entitlements, they lack the empowerment to adapt, locking them into a vulnerable situation. Other constraints include poor extension services $(\bar{x}=2.61)$, high cost of information materials $(\bar{x}=2.60)$ and inadequate information $(\bar{x}=2.31)$. This implies that information limits adaptation. UNEP (2009); Scheraga and Grambsch (1998), asserted that inadequately trained personnel can limit a community's or a nation's ability to implement adaptation options. Therefore, it is important to develop appropriate systems, both at local and national levels, to disseminate weather and climate change information, and to make options and adaptive strategies available for various regions and farming systems.

Table 4: Constraints to accessing climate change information

\begin{tabular}{|c|c|c|c|c|c|c|}
\hline \multirow[t]{2}{*}{ Constraints } & \multicolumn{2}{|c|}{ Male } & \multicolumn{2}{|c|}{ Female } & \multicolumn{2}{|c|}{ Total } \\
\hline & Mean & SD & Mean & SD & Mean & SD \\
\hline Unavailability of funds & $2.85^{*}$ & .46 & $2.88^{*}$ & .43 & $2.86^{*}$ & .45 \\
\hline Poor access to land & $2.74^{*}$ & .55 & $2.81^{*}$ & .49 & $2.76^{*}$ & .53 \\
\hline Inadequate storage facilities & $2.72^{*}$ & .61 & $2.88^{*}$ & .43 & $2.76^{*}$ & .58 \\
\hline Poor extension services & $2.64^{*}$ & .65 & $2.50^{*}$ & .71 & $2.61^{*}$ & .66 \\
\hline High cost of information materials & $2.59^{*}$ & .65 & $2.65^{*}$ & .56 & $2.60^{*}$ & .63 \\
\hline $\begin{array}{l}\text { Inadequate means of disseminating } \\
\text { information }\end{array}$ & $2.50^{*}$ & .70 & $2.38^{*}$ & .70 & $2.47^{*}$ & .70 \\
\hline Low level of technologies & $2.40^{*}$ & .59 & $2.46^{*}$ & .51 & $2.42^{*}$ & .57 \\
\hline Inadequate information and knowledge & $2.34^{*}$ & .52 & $2.19^{*}$ & .49 & $2.31^{*}$ & .52 \\
\hline Poor/unfavourable government policy & $2.26^{*}$ & 67 & $2.42^{*}$ & .64 & $2.29^{*}$ & 67 \\
\hline Lack of improved variety of seeds & $2.28^{*}$ & .68 & $2.12^{*}$ & .59 & $2.24^{*}$ & .66 \\
\hline Lack of improved planting methods & 1.79 & 62 & 1.77 & .59 & 1.78 & 61 \\
\hline High flooding/ erosion rate & 1.50 & .71 & 1.27 & .53 & 1.45 & .68 \\
\hline High infestation of pest and diseases & 1.39 & .59 & 1.35 & .49 & 1.38 & .57 \\
\hline
\end{tabular}

Source: Field survey, 2014

Mean> $2.00=$ Serious 
Creative commons User License: CC BY-NC-ND

Abstracted by: EBSCOhost, Electronic Journals Service (EJS),

Google Scholar, Directory of Open Access Journals (DOAJ),

Journal Seek, Scientific Commons,

Food and Agricultural Organization (FAO), CABI and Scopus
Journal of Agricultural Extension

Vol. 21 (3) October, 2017

ISSN(e): 24086851; ISSN(Print); 1119944X

http://journal.aesonnigeria.org

http://www.ajol.info/index.php/jae

Email: editorinchief@aesonnigeria.org

\section{Difference Between Male and Female on Trainings in CCAPs in Oil Palm Production}

Table 5 shows the result of $\mathrm{t}$-test analysis of the difference between the gender categories with respect to training needs on climate change adaptation on oil palm production practices. No significant difference exists between male and female respondents $(\overline{\mathrm{x}}=50.06<50.35)$ This is an indication that both gender require skills in these practices to the extent in which they are involved in oil palm production however, this difference is not statistically significant.

Table 5: Difference between male and female on trainings in climate change adaptation practices in oil palm production

\begin{tabular}{|c|c|c|c|c|}
\hline \multirow[t]{2}{*}{ Sex } & \multirow[t]{2}{*}{$\mathbf{N}$} & \multicolumn{2}{|c|}{ Training need score } & \multirow[t]{2}{*}{ t- value } \\
\hline & & & Difference & \\
\hline Male & 94 & 50.06 & 0.282 & 0.31 \\
\hline Female & 26 & 50.35 & & \\
\hline
\end{tabular}

\section{Difference Between Male and Female on Trainings in Postharvest Climate Change Adaptation Practices}

Table 6 shows the result of t-test analysis of the difference between gender categories with respect to training needs on climate change adaptation oil palm post harvest practices. Significant difference existed between male and female respondents $(\overline{\mathrm{x}}=24.65<27.96)$. This is an indication that the females require more trainings in post-harvest CCAPs that their male counterparts. This is also a pointer to the fact that females were more involved in post harvest practices of oil palm than the males. This is in line with the assertion of Sarku (2016) who stated that women are more involved in the marketing and processing of oil palm than the men.

Table 6: Difference between male and female on trainings in post-harvest climate change adaptation practices

\begin{tabular}{llccc}
\hline \multicolumn{1}{c}{ Sex } & N & \multicolumn{2}{c}{$\begin{array}{c}\text { Training need score } \\
\text { Mean }\end{array}$} & t- value \\
& & Difference & \\
\hline Male & 94 & 24.65 & 3.31 & 7.034 \\
Female & 26 & 27.96 & & \\
\hline
\end{tabular}

Source: Field survey, $2014 \quad$ Significant $\quad$ Critical value at $5 \%=1.96$

\section{Conclusion and Recommendations}

Male and female oil palm farmers perceived several climate change adaptation practices as relevant. Training needs expressed for oil palm climate change related production practices were similar for both gender but females indicated higher need for post-harvest adaptation practices. Constraints to knowledge in climate change adaptation practices bothered on discouragement due to poor access to resources, education and dearth of technologies. Edo State ADP and NGOs in the state should embark on capacity building for both male and females on climate change related oil 
Creative commons User License: CC BY-NC-ND

Abstracted by: EBSCOhost, Electronic Journals Service (EJS), Google Scholar, Directory of Open Access Journals (DOAJ), Journal Seek, Scientific Commons,

Food and Agricultural Organization (FAO), CABI and Scopus
Journal of Agricultural Extension

Vol. 21 (3) October, 2017

ISSN(e): 24086851; ISSN(Print); 1119944X

http://journal.aesonnigeria.org

http://www.ajol.info/index.php/jae

Email: editorinchief@aesonnigeria.org

palm production and post-harvest practices. However, females should be targeted more in post-harvest skill development.

Constraints to knowledge in climate change adaptation practices could be ameliorated through Edo State ADP, Farmers' organization and NGOs mobilizing oil palm entrepreneurs into commodity groups to build their confidence, capacity to access production resource and improve knowledge and skill in CCAP in oil palm value chain. Dissemination of CCAPs information through several channels including extension agents should be pursued more rigorously to enhance performance in oil palm value chain in Edo State.

\section{References}

Agwu E. A. (2006). Status of fish farming in Isoko Area of Niger Delta Nigeria; Implications for extension and global approaches to extension practices. Journal of Agricultural Extension, 2(2), 0794-1005.

Alamu, J. F. and Rahman, S. A. (2002). Agricultural supply response. Evidence from four cereal crops in Nigeria. The Nasarawa Journal of Humanities, 1(1), $198-203$.

Ayodele, T. (2010). African case study: Palm Oil and economic development in Nigeria and Ghana; Recommendations for the World Bank's 2010 Palm oil strategy. Initiative for Public Policy Analysis Lagos, Nigeria. http://www.ippanigeria.org. 1-13. Accessed 3rd January, 2011.

Basiron, Y. (2007). Palm oil production through sustainable plantations. European Journal Lipid Science Technology, 109: 289-295.

Corley, R. H. V. and Tinker, P. B. (2003). The Palm Oil. 4th Edition, Blackwell Publishing, Oxford, UK.

Dankelman, I., ed. (2010). Gender and Climate Change: An Introduction. London: Earthscan.

Erhabor, P.O. and Emokaro, C.O. (2007). Relative technical efficiency of cassava farmers in the three agro-ecological zones of Edo State, Nigeria. Journal of Applied Sciences, 7: 2818-2823.

Food and Agriculture Organisation, (FAO). (2011). The state of Food and Agriculture. Rome: Italy

Food and Agriculture Organisation, (FAO). (2007). The Digital Soil Map of the World. Version $\quad 3.6$ (January), Rome, Italy

Gunn, P. and Nnadi, J. A. (2013). Role of information on adoption of improved Palm oil processing technologies in Delta State, Nigeria. International Journal of Agricultural Sciences and Veterinary Medicine, 1(4), 81-86

Intergovernmental Panel on Climate (IPCC). (2007). Climate Change 2007: Impacts, Vulnerability and Adaptation. WMO, Geneva. Kates, R. W. (1985). The interaction of climate and society. In R. W. Kates, J. A. Ausubel and M. Berberian (eds) Climate impact assessment. SCOPE 27, John Wiley \& Sons Ltd., Chichester. pp 3-36.

Intergovernmental Panel on Climate (IPCC). (2001). Climate change 2001. Impacts, vulnerability and adaptation. Contribution of working group III to the third assessment report on the Intergovernmental Panel on Climate Change 2007. Cambridge University Press, Cambridge.

International Water Management Institute (IWMI). 2009. The Agricultural Water Management (AWM) solutions project: Improved livelihoods for smallholder farmers. A 3 year (20092011) project funded by the Bill \& Melinda Gates Foundation being undertaken by IWMI, IFPRI, IDE, SEI, FAO and CH2M HILL in Africa and South Asia. http://awmlandscape.iwmi.org/project-overview.aspx 
Creative commons User License: CC BY-NC-ND

Abstracted by: EBSCOhost, Electronic Journals Service (EJS),

Google Scholar, Directory of Open Access Journals (DOAJ),

Journal Seek, Scientific Commons,

Food and Agricultural Organization (FAO), CABI and Scopus

\section{Journal of Agricultural Extension}

Vol. 21 (3) October, 2017

ISSN(e): 24086851; ISSN(Print); $1119944 X$

http://journal.aesonnigeria.org

http://www.ajol.info/index.php/jae

Email: editorinchief@aesonnigeria.org

Li, X. T., Takahashi, N. S. and Kaiser, H. M. (2011). The impact of climate change on maize yields in the United States and China. Agricultural System, 104: 348-353.

National Oceanic and Atmospheric Administration (NOAA). (2011). Ocean and coastal resource management in your state and territories working with National Oceanic and Atmospheric Administration.

Nigeria Institute for Oil Palm Research (NIFOR) (2006), Annual report, available at http://www.nifor.org/about.htm. Accessed 10th June, 2010

Obinne, C. P. O., Anyanwu, A. C. (1991). Communication Factors Determining Adoption of Improved Cassava Technologies in Small-holder Agriculture. Nigerian Journal of Rural Extension and Development, 1 (1), 15-23.

Odior, A. O. (2007). Application of Time Study Model in an Oil palm processing company, A case study. Pacific Journal of Science, Benin City, Nigeria. www.akamaiuniversity.us/PJST.htl. Accessed 26th June, 2010.

Okpamen, S. U., Umumarongie-Ilori, E. G., Orhue, E. R., Suilaman-Ilobu, B. B., Eneje, R. C. and Efetie-Osie, A. (2012). Influence of climatic factors on soil reaction, nutrient application and yield outputs of oil palm, International Research Journal of Plant Science, 3(10) pp. 216-221

Oladipo, J. A. (2008). Agro-industry as strategy for rural development: An impact assessment of Nigeria Oil palm industry. European Journal of Social Sciences, 7(1): 75-87.

Omereji, G. O. (2005). The Oil Palm industry in Nigeria: Cultivation, processing and trade. Mindex publishers, Benin City. 131-156

Rosillo-Calle, F., Pelkmans, L. and Walter, A. (2009). A Global Overview of Vegetable Oils, with Reference to Biodiesel. A Report for the IEA Bioenergy Task 40. IEA Bioenergy, (2009).

Sarku, R. (2016). Analyses of gender roles in the Oil palm industry in Kwaebibirem District, Ghana. International Journal of Humanities and Social Science, 6(3), 187-198

Scheraga, J. and Grambsch, A. (1998), Risks, Opportunities, and Adaptation to Climate Change. Climate Research, 10, pp. 85-95.

Toulmin, C. (2009). Climate change in Africa. Zed Books, London.

United Nations Development Programme Africa. (2011). Adaptation experiences gender and climate change: Advancing development through an integrated gender perspective, Vol. 1.

United Nations Development Programme (UNDP). (2010). Gender, climate change and community-based adaptation, New York

United Nations Environment Programme (UNEP). (2011). Global environment outlook 3: Past, present and future perspectives. Earthscan publication, London.

United Nations Environment Programme (UNEP). (2009). Climate information and capacity needs for ecosystem management under a changing climate. White paper prepared for the world climate Conference - 3 Geneva, Switzerland, 31 August - 4 September 2009. Climate change adaptation unit, UNEP, Nairobi, Kenya. http://www. wcc3.org/wcc3docs/pdf/WS7_WP_needs.doc

United States Agency for International Development (USAID). (2005). Enhancing women's access to markets: An overview of donor programs and best Practices http://pdf.usaid.gov/pdf docs/PNADH668.pdf

Women Watch (2009). Fact Sheet: Women, gender equality and climate change. 
Creative commons User License: CC BY-NC-ND

Abstracted by: EBSCOhost, Electronic Journals Service (EJS), Google Scholar, Directory of Open Access Journals (DOAJ), Journal Seek, Scientific Commons,

Food and Agricultural Organization (FAO), CABI and Scopus
Journal of Agricultural Extension

Vol. 21 (3) October, 2017

ISSN(e): 24086851; ISSN(Print); 1119944X

http://journal.aesonnigeria.org

http://www.ajol.info/index.php/jae

Email: editorinchief@aesonnigeria.org 